\title{
Tanner Colby, Some of My Best Friends are Black (2012)
}

James W. Gentry

University of Nebraska-Lincoln

Follow this and additional works at: https://digitalcommons.uri.edu/mgdr

Part of the American Politics Commons, Anthropology Commons, Economics Commons, Marketing Commons, Other Business Commons, Social Justice Commons, Social Policy Commons, and the Sociology Commons

\section{Recommended Citation}

Gentry, James W. (2020) "Tanner Colby, Some of My Best Friends are Black (2012)," Markets, Globalization \& Development Review. Vol. 5: No. 2, Article 6.

DOI: 10.23860/MGDR-2020-05-02-06

Available at: https://digitalcommons.uri.edu/mgdr/vol5/iss2/6

This Book Review is brought to you for free and open access by DigitalCommons@URI. It has been accepted for inclusion in Markets, Globalization \& Development Review by an authorized editor of DigitalCommons@URI. For more information, please contact digitalcommons-group@uri.edu. 
Tanner Colby, Some of My Best Friends are Black (2012)

\section{Markets, Globalization \& Development Review}
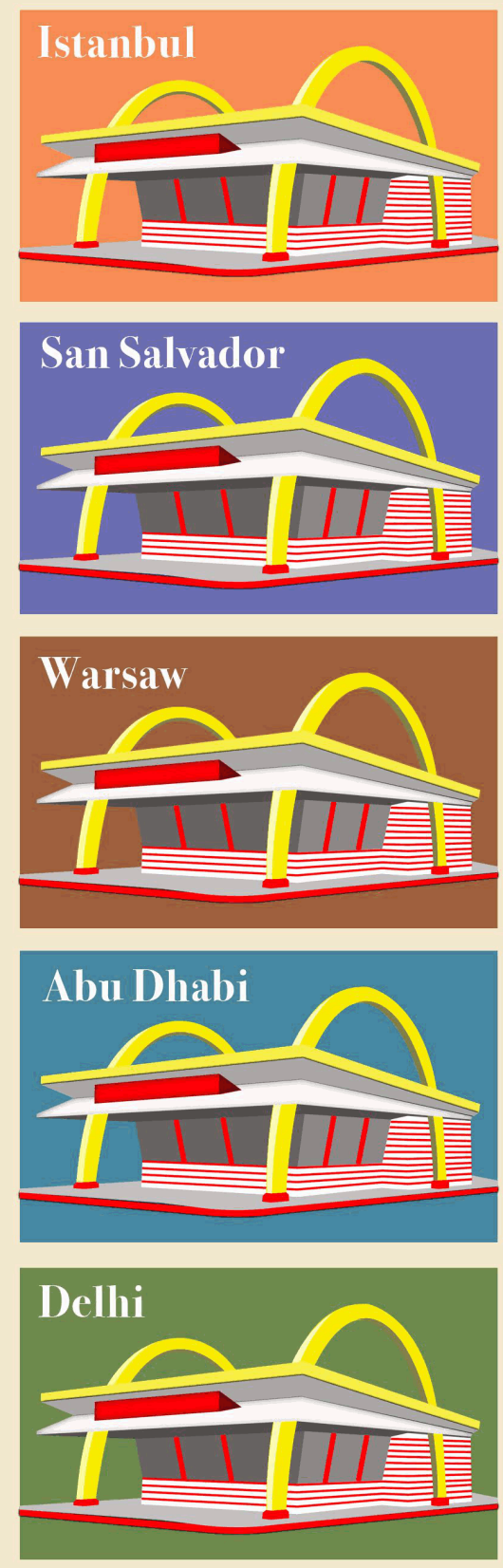
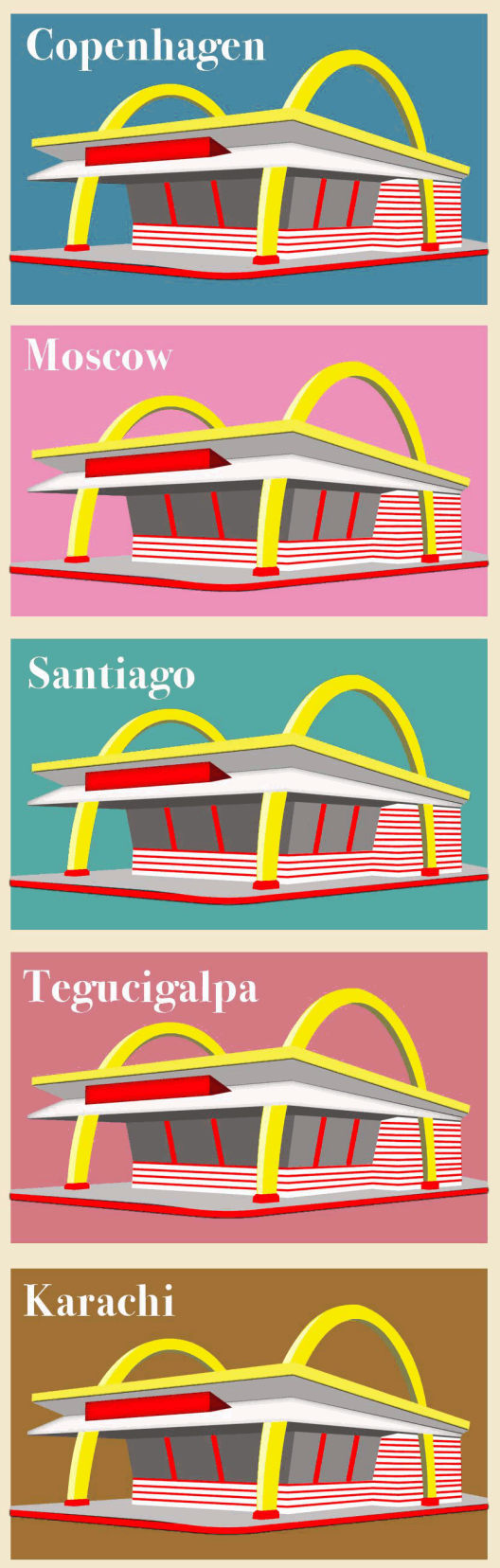
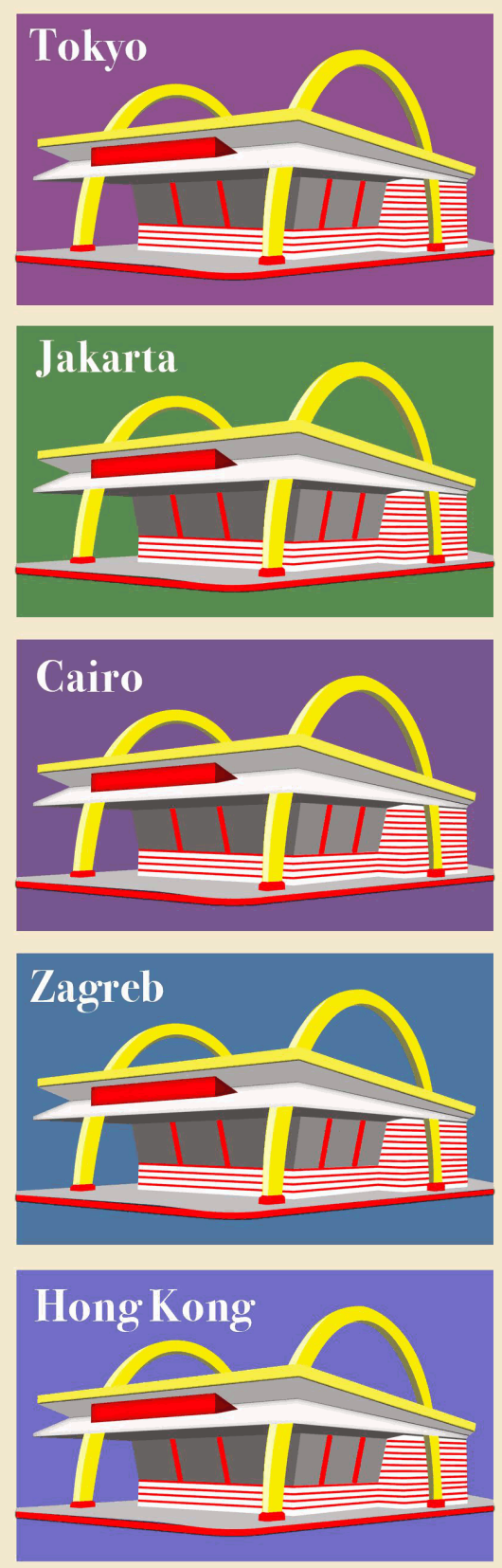

This book review is available in Markets, Globalization \& Development Review: https://digitalcommons.uri.edu/mgdr/ vol5/iss $2 / 6$ 


\section{Book Review}

\section{Tanner Colby, Some of My Best Friends are Black (2012)}

\section{Introduction}

While the Colby book is not particularly recent, it certainly can help us to understand better the renewed and expanded vigor of the Black Lives Matter (BLM) movement in the United States in 2020. In the book, there is little to no discussion of the brutal treatment of blacks by police, but there is a strong case established for Colby's contention that racial integration has not worked, especially the use of school busing. The book was well received when first published as it made the New York Times bestseller list, but the events of 2020 have made it an even more relevant work. The review in Ebony called it "irresistibly readable" and the one in Publishers' Weekly called it "charming and surprisingly funny".

The first two sections of the book dealt with the efforts made to meet the Civil Rights standards set by Congress and subsequent Supreme Court decisions (Civil Rights Act of 1964; Lyndon Johnson's Executive Order 11246 of 1965). Prior to the 1950s, blacks and whites had their own schools, which were supposedly separate but equal. With a few exceptions, the educational experiences and achievements of the white students were far superior to those of black students. The 1954 Supreme Court case Brown vs. the Board of Education of Topeka ruled that "separate but equal" was unconstitutional and that racial segregation of children in public schools was not permitted. On a personal note, the reviewer of this book is proud that the court case started in his hometown, as he was attending a Topeka elementary school when the decision was made. He later ran track in high school with the son of one of the local lawyers who started the court case. Returning to our narrative, Brown's case was about his daughter having to walk about twice as far from her residence to her black school as opposed to the nearest white school. The true cause of school segregation, however, was the nature of housing patterns in most cities. In many states, busing of children to black and white schools was done in order to reach the racial mix specified by law. While blacks and whites now attended school together, few fully experienced integrations. For example, in the cafeterias, the black table was at a distance from the white tables. 


\begin{abstract}
Alabama
The early emphasis in the book was on the situation in Birmingham, Alabama, where Colby had attended school and which he labeled the most segregated city in the United States. Throughout the book, Colby interviewed informants about their lived experiences during the integration efforts. The most successful (by white standards: those who went on to universities and professional careers) black students had felt isolated. Most white students accepted them as peers, but some bigotry was encountered. Crockett (2017) provides similar perspectives in his discussion of how adult blacks faced tensions when they moved into white middle class neighborhoods. The black students now in white schools also found their black friends not to be generally supportive, especially those who were bused into a new school district. Crockett and Wallendorg (2004) discuss the rejections that blacks in Milwaukee moving into white neighborhoods received from former friends in their old neighborhoods. Integration was stymied by "white flight", as white parents moved to growing suburbs where, in several cases, avoidance of racial mix standards was still possible.
\end{abstract}

\title{
Kansas City
}

The second section of the book looks at Kansas City, Missouri, and how actions of two developers resulted in very volatile housing patterns. One developer bought land on the Kansas side of the Missouri River, and built houses attracting white flight from the Missouri side. Troost Avenue on the Missouri side had served the traditionally symbolic role of 'railroad tracks' in separating the richer, white areas from the poorer, largely black, areas. Prior to forced integration, some Black schools were quite good. That quality diminished with integration confusion. Black parents became quite worried about their children's educations, and developers tempted them with housing opportunities on the other side of Troost. At that time, Blacks were ineligible for mortgages from government sources, and the developers provided mortgage opportunities at ridiculously high rates, leading to very high default rates. Bone, Christensen, and Williams (2014) found that obtaining mortgages is still far easier for whites than for blacks with comparable credentials. Unethical developers are not unique to the U.S., but neither are they uncommon. Consider the economic crisis in the United States (and then throughout most of the world) in 2007-2008 when first-time homeowners were tempted with relatively small down payments with ballooning interest rates. 


\section{Madison Avenue}

The third section of the book discusses the advertising industry. Madison Avenue has traditionally been white, due in part to the assumption that black advertisers would not understand the white majority market well. Over time, blacks were hired by white advertising companies (which, later, was a premise of the TV show "Blackish"), due in part to the acknowledgment that there is a potentially profitable market of black consumers. A bigger reason for the black hiring was the governmental pressure to diversify employment (the 1969 version of the Philadelphia Plan in President Richard Nixon's government). Interviews - with some of the early few blacks in predominantly white Madison Avenue - yielded insight as to the role of the "good-old-boy" network in advertising. Even those with truly unique abilities needed someone well entrenched in the system to look out for them. The role of relationships in business transactions has much coverage in the marketing literature. When the primary market was seen to be white, the individuals who were hired to reach the market were of course white, given the assumption that black and white cultures differ greatly. Thus, the good-old-boy network proved to be a barrier that has only been overcome haltingly and slowly. Globally the U.S. has been the primary generator of advertising given its role in the world economy. The U.S.'s marketing focus on the top $15 \%$ of the world's population has resulted in some truly bad advertising campaigns in the developing world. Colby states that, in order to sell anything, you need to understand people. Failure to do so leads to his conclusion that "... good advertising is really hard to do, and most of it sucks" (p.213).

\section{Religion}

The last section of the book dealt with the role of religion in creating differences. Most American blacks and whites are Christian, which one might think would facilitate some commonality across the races. In reality, however, Colby noted that "by the most widely cited statistic, 93 percent of all churches in America are racially homogeneous" (p.278). Most Blacks are Protestant, due in part to the antagonism of Catholics in the South in the post-Civil War Reconstruction times. Colby acknowledges the strong role of the Black Church: "it's the social, economic, political, and cultural hub of a separate Black America" (p. 278).

\section{Concluding Observations}

For me, the most insightful section of the book is the discussion of the two Catholic churches in Grand Coteau, Louisiana. Colby provides discussion 
of Catholicism in Louisiana, which - due to the state's French, Spanish, Cajun, and Creole roots - enabled the religion to survive there. Grand Coteau is a small town of about one thousand people, but it had two Catholic churches, one black and one white. He detailed a discussion of how 13 successive priests made efforts to unite the two churches. Many of the priests left due to the frustration they encountered in these efforts. From an economic perspective, the integration was a no-brainer. There was, however, much resistance on the part of both churches to a merger. Even after blacks were permitted to attend services at the white church, most blacks preferred to attend their own church. Time was hard on the Black Church's building, which was in need of many repairs. Hurricane Lilly further damaged it in 2002 . The 13th priest was 78 years old, and in charge of both churches. While the efforts of previous priests had resulted in strong animosity from members of both churches, No. 13 appealed that he was physically not able to manage both churches. This personalized appeal generated sufficient sympathy for the merging of the two memberships into what had previously been the White Church. Colby's coverage provides great insight into why many blacks did not wish to become members of the more attractive and better built White Church.

I found the book to be quite enlightening. I do have black friends, one sufficiently close to have had meaningful discussions about racial perspectives. My most enjoyable academic process was working with doctoral students, a number of whom were people of color. Yet the Colby book exposed me to many new perspectives.

The book's focus on race in the United States may seem to limit its insights about markets, globalization and development. Crockett noted (2017, p.554) that "racial inequity ... is not a problem unique to the U.S." Further, almost all countries face issues of discrimination in some context. Native peoples have not been treated well historically. Religious discrimination is very visible in the Middle East, China, India, and many other countries in the world. Birth-based caste and royalty/nobility/commoner distinctions continue to be problematic in India, Britain (see, e.g., the popular Netflix series "The Crown"), Africa and other regions. Gender discrimination exists everywhere, to varying degrees. Greater understanding of those who are different from the mainstream in power is clearly needed for most of us. This book can be a stepping stone in meeting that need. 


\section{References}

Bone, Sterling A., Glenn L. Christensen, and Jerome D. Williams (2014), "Rejected, Shackled, and Alone: The Impact of Systemic Restricted Choice on Minority Consumers' Construction of Self," Journal of $\begin{array}{lllll}\text { Consumer } & \text { Research, } & 41 & \text { (2), }\end{array}$ https://doi.org/10.1086/676689

Colby, Tanner (2013), Some of My Best Friends are Black: The Strange Story of Integration in America. New York: Penguin.

Crockett, David (2017), "Paths to Respectability: Consumption and Stigma Management in the Contemporary Black Middle Class," Journal of Consumer Research, 44 (3), 554-81. https://doi.org/10.1093/jcr/ucx049

Crockett, David and Melanie Wallendorf (2004), "The Role of Normative Political Ideology in Consumer Behavior," Journal of Consumer Behavior, 31 (3), 511-28. https://doi.org/10.1086/425086 